Vol 1, No 2, Desember 2020; 149-163

e-ISSN : 2723-3324

Available at: e-journal.sttberitahidup.ac.id/index.php/jan/index

\title{
Iman Kristen dan Perundungan di Era Disrupsi
}

\author{
Yonatan Alex Arifianto ${ }^{1,2}$ \\ arifianto.alex@sttsangkakala.ac.id \\ Joseph Christ Santo ${ }^{3}$ \\ jx.santo@gmail.com
}

\begin{abstract}
Social media is actually used to improve social relationships and increase roles in various ways. However, on the one hand, social media is used as an arena for bullying to others and groups. The problem in this research is how the role of Christian faith. Using a descriptive qualitative method with a literature study approach, this research comes to the conclusion that believers must know the era of disruption in human social development, then understand the influence of social media on ethics, and examine how Christian faith views in the face of bullying. Holding on to the view that the Christian existence must be the salt and light of the world means that we must be prepared to live side by side with physical differences, ideas, and all other things.
\end{abstract}

Keywords: bullying, disruption, Christian faith, social media

\begin{abstract}
Abstrak
Media sosial sejatinya digunakan untuk meningkatkan hubungan sosial dan meningkatkan peran dalam berbagai hal. Namun dalam satu sisi media sosial dijadikan ajang perundungan (bullying) kepada sesama maupun kelompok. Masalah dalam penelitian ini adalah bagaimana peran iman Kristen. Menggunakan metode kualitatif deskriptif dengan pendekatan studi literatur, penelitian ini sampai pada kesimpulan bahwa orang percaya harus mengetahui era disrupsi dalam perkembangan sosial manusia, lalu memahami adanya pengaruh media sosial dalam etika, dan mencermati bagaimana pandangan iman Kristen dalam menghadapi perundungan. Dengan berpegang pada pandangan bahwa keberadaan orang Kristen harus menjadi garam dan terang dunia, berarti harus siap hidup berdampingan dengan perbedaan fisik, ide, dan segala hal lainnya.
\end{abstract}

Kata-kata kunci: perundungan, bullying, disrupsi, iman Kristen, media sosial

\footnotetext{
${ }^{1}$ Dosen Sekolah Tinggi Teologi Sangkakala

${ }^{2}$ Mahasiswa Pascasarjana Sekolah Tinggi Teologi Berita Hidup

${ }^{3}$ Dosen Sekolah Tinggi Teologi Berita Hidup
} 


\section{PENDAHULUAN}

Perkembangan kemajuan teknologi terjadi di segala lini, khususnya teknologi informasi, merupakan salah satu kemajuan yang pesat pada masa sekarang, yang kerap disebut era disrupsi. Peran teknologi informasi dan internet menjadi dasar kemudahan bagi manusia dalam menjalin bisnis, pertemanan, bahkan menjadi ajang personal branding bagi seseorang. Adanya media sosial dalam kecanggian teknologi informasi mengakibatkan dampak perubahan dalam berkomunikasi dan bersosialisasi. Bahkan setiap pengguna internet dapat dengan mudah mempublikasikan emosi dan pikirannya di internet, termasuk di dalamnya emosi negatif yang ditujukan untuk menyakiti orang lain. ${ }^{4}$ Kasus demi kasus, persoalan demi persoalan akan terus terjadi seiring dengan perkembangan kemajuan dunia teknologi dan informatika. Berkembangnya gadget atau gawai, tentu akan mengembangkan media-media sosial baru. Sementara perkembangan media sosial tersebut, mau tidak mau, sadar atau tidak sadar akan menghasilkan dampak yang buruk, salah satunya adalah perundungan siber atau perundungan di dunia maya. ${ }^{5}$ Secara umum perundungan di dunia maya didefinisikan sebagai perilaku kekerasan yang berlangsung di dunia maya, ${ }^{6}$ yang dapat mengakibatkan dampak negatif bagi korban secara nyata. Ini merupakan persoalan serius yang memberikan dampak negatif, ${ }^{7}$ dan yang sangat fatal bagi korban. ${ }^{8}$

Perundungan merupakan perilaku negatif berulang yang bertujuan untuk membuat orang lain tidak senang atau tersakiti, yang dilakukan oleh satu atau beberapa orang pada seseorang yang tidak dapat melawan. ${ }^{9}$ Kasus mengenai perundungan banyak terjadi di berbagai negara termasuk Indonesia. Di Indonesia sering kali orang menganggap perundungan sebagai hal yang biasa terjadi. Kasus perundungan yang banyak ditemukan di lembaga pendidikan adalah senioritas atau adanya intimidasi dari siswa senior pada adik kelasnya, baik secara fisik maupun non-fisik. ${ }^{10}$ Secara khusus bentuk perundungan maya yang dialami korban berupa ejekan, fitnahan, ancaman, dan objek gosip. Pelaku merundung

\footnotetext{
${ }^{4}$ Neila Ramdhani, "Emosi Moral dan Empati pada Pelaku Perundungan-siber,” Jurnal Psikologi 43, no. 1 (2016): 66 .

${ }^{5}$ Ranny Rastati, "Bentuk Perundungan Siber Di Media Sosial Dan Pencegahannya Bagi Korban Dan Pelaku,” Jurnal Sosioteknologi 15, no. 2 (2016): 169-186.

${ }^{6}$ Sartana Dan dan Nelia Afriyeni, "Perilaku Perundungan Maya (Cyberbullying) Pada Remaja Awal," Jurnal Psikologi Insight (C) Psikologi Universitas Pendidikan Indonesia 1, no. 1 (2017): 25-41.

7 Fildzah Rudyah Putri, "Hubungan Pola Asuh Otoriter Terhadap Perilaku Perundungan Pada Remaja,” JKKP (Jurnal Kesejahteraan Keluarga dan Pendidikan) 5, no. 2 (2018): 101-108.

${ }^{8}$ Ihsana Sabriani Borualogo, Hedi Wahyudi, dan Sulisworo Kusdiyati, "Prediktor perundungan siswa sekolah dasar," Jurnal Ilmiah Psikologi Terapan 8, no. 1 (2020): 35.

9 Rini Kartikosari dan Imam Setyawan, "Hubungan Kecerdasan Interpersonal Dengan Intensi Perundungan Pada Siswa Sekolah Menengah Pertama H. Isriati Semarang,” Empati 7, no. 2 (2018): 182-188. ${ }^{10}$ Ibid.
} 
korban sekadar untuk bercanda atau balas dendam, tetapi ada juga yang melakukannya dengan memanfaatkan kesempatan untuk menyembunyikan identitas. Akibat dari perundungan maya menyebabkan korban merasa marah, malu, tidak bisa konsentrasi belajar, dan takut. Dampak krisis mental perundungan maya lebih serius dibanding dengan perundungan di dunia nyata. ${ }^{11}$

Dengan permasalahan di atas penulis bertujuan mendeskripsikan peran iman Kristen dalam menghadapi perundungan dalam dunia maya sehingga dapat memberikan pemahaman kepada orang percaya. Penelitian tentang perundungan di dunia maya tersebut sudah banyak dilakukan oleh peneliti sebelumnya yang telah mengkaji tentang topik tersebut. Pada umumnya, penelitian tersebut hanya fokus pada satu pihak yang dalam peristiwa perundungan maya. Namun penulis menuangkan sikap iman Kristen dan era disrupsi yang menjadi fokus penelitian.

\section{METODOLOGI}

Penelitian dalam paper ini adalah penelitian pustaka dengan pendekatan kualitatif deskriptif $^{12}$. Penulis melakukan kajian terhadap sumber-sumber pustaka dan menguraikannya dalam sebuah kerangka uraian dengan mendeskripsikan perundungan dalam era disrupsi. Penulis juga melakukan studi pustaka terhadap berbagai sumber literatur berupa jurnal teologi ataupun buku-buku yang sesuai dengan tema, sehingga diperoleh gambaran tentang konsep iman Kristen dalam memahami dan mengaktualisasikan tindakan yang sesuai dengan Firman yang berkaitan dengan perundungan di era disrupsi ini. Selain menggunakan Alkitab sebagai referensi primer, juga dipergunakan buku-buku dan sumbersumber primer lain yang relevan dengan topik sesuai prinsip literatur review yang dimaksud oleh Denney ${ }^{13}$.

\section{PEMBAHASAN}

Tindak kejahatan yang terjadi di era globalisasi adanya perundungan atau bullying yang ditujukan untuk merendahkan orang lain. Bullying sendiri berasal dari bahasa Inggris, yaitu dari kata bull yang berarti banteng yang suka menyeruduk kesana kemari. ${ }^{14}$ Istilah

\footnotetext{
${ }^{11}$ Dan dan Afriyeni, "Perilaku Perundungan Maya (Cyberbullying) Pada Remaja Awal."

12 Sonny Eli Zaluchu, "Strategi Penelitian Kualitatif dan Kuantitatif Di Dalam Penelitian Agama," Evangelikal: Jurnal Teologi Injili dan Pembinaan Warga Jemaat 4, no. 1 (2020): 28-38.

13 Andrew S. Denney dan Richard Tewksbury, "How to Write a Literature Review," Journal of Criminal Justice Education 24, no. 2 (2013): 218-234.

${ }^{14}$ Riauskina Djuwita dan Soesetro, Psikologi Remaja Perkembangan Peserta Didik, (Jakarta: Bumi Aksara, 2001), 46.
} 
aslinya berasal dari bahasa Inggris, yaitu mob yang menekankan bahwa biasanya $m o b$ adalah kelompok orang yang anonim tak jelas dan berjumlah banyak serta sering terlibat kekerasan. ${ }^{15}$ Sedangkan bullying, dalam Bahasa Indonesia dikenal dengan istilah perundungan, umumnya terjadi di lingkungan pelajar dan banyak dialami oleh anak-anak. Namun pada kenyataannya, perundungan dapat terjadi di berbagai bidang kehidupan, mulai dari lingkungan sekolah hingga lingkungan profesi. ${ }^{16}$ Bukan hanya terjadi di kalangan selebritas, perundungan juga dapat menimpa kalangan pelajar, politikus, bahkan institusi pemerintah. ${ }^{17}$ Perundungan maya sendiri secara spesifik adalah tindakan ditujukan untuk mempermalukan, mengintimidasi, menyebar keburukan dan kebencian di media internet atau siber baik ditujukan secara khusus kepada korban maupun dengan cara diketahui publik. ${ }^{18}$ Dengan mengarahkan pada tindakan melukai, atau membuat korban merasa tidak nyaman. Tindakan di atas bermula dari intimidasi secara verbal (memanggil dengan nama buruk, mengancam, mengolok-olok, jahil, menyebarkan isu buruk, perkataan kotor), sampai menumpuk dan akhirnya dapat dilakukan secara fisik (pemukulan, tendangan, mendorong, mencekik, dan lainya), atau tindakan lain seperti memasang muka dan melakukan gerakan tubuh yang melecehkan (secara seksual) atau secara terus menerus mengasingkan korban dari kelompoknya. ${ }^{19}$

Era yang maju dengan kecanggihan teknologi dan informasi serta adanya globalisasi banyak plus dan minusnya, namun salah satu dampak negatifnya yang memprihatinkan dari adanya kecanggihan teknologi ini adalah munculnya perilaku yang tidak mengedepankan moral, menghina, mencaci, dan menyakiti orang lain, ${ }^{20}$ salah satunya adalah perundungan yang melibatkan media sosial atau bisa disebut perundungan maya, bentuk agresi yang dilakukan melalui media sosial dan teknologi informasi dan komunikasi. ${ }^{21}$ Perundungan di dunia daring ini sangat mudah dilakukan dan cenderung aman. Perundungan di media maya

15 Yayasan Semai Jiwa Amini (Sejiwa), Perundungan: Mengatasi Kekerasan di Sekolah dan Lingkungan Sekitar Anak. (Jakarta : Grasindo, 2008), h. 2.

${ }^{16}$ Anna Rozaliyani et al., "Bullying (Perundungan) di Lingkungan Pendidikan Kedokteran,” Jurnal Etika Kedokteran Indonesia 3, no. 2 (2019): 56.

17 Rastati, "Bentuk Perundungan Siber Di Media Sosial Dan Pencegahannya Bagi Korban Dan Pelaku."

${ }^{18}$ Rulli Nasrullah, "Perundungan Siber ( Cyber - Bully Ing ) Di Status Facebook Divisi Humas Mabes Polri,” Jurnal Sosioteknologi 14, no. 1 (2015): 1-11.

${ }^{19}$ Nursasari Nursasari, "Penerapan Antisipasi Perundungan (Bullying) pada Sekolah Dasar di Kota Tenggarong," SYAMIL: Jurnal Pendidikan Agama Islam (Journal of Islamic Education) 5, no. 2 (2017). Pelaku."

${ }^{20}$ Rastati, "Bentuk Perundungan Siber Di Media Sosial Dan Pencegahannya Bagi Korban Dan

${ }^{21}$ Justin W. Patchin dan Sameer Hinduja, "Bullies Move Beyond the Schoolyard: A Preliminary Look at Cyberbullying," Youth Violence and Juvenile Justice 4, no. 2 (2006): 148-169. 
bisa dilakukan oleh identitas yang disembunyikan. ${ }^{22}$ Perundungan ini dilakukan oleh akunakun yang disamarkan dan secara bebas mengomentari setiap status yang dipublikasikan, baik dalam bentuk kata-kata maupun gambar, ${ }^{23}$ yang menyerang secara pribadi dengan sikap merendahkan dan mempermalukan korban. Memang pada awalnya penggunaan awal jejaring sosial sebagai media mencari informasi dan menjalin pertemanan namun mulai dijadikan sebagai media dalam melakukan perundungan. ${ }^{24}$

\section{Era Disrupsi dalam Perkembangan Sosial Manusia}

Industri 4.0 dikatakan era disrupsi teknologi karena otomatisasi dan konektivitas di sebuah bidang akan membuat pergerakan dunia industri dan persaingan kerja menjadi tidak linier. Perubahan yang terus terjadi sekarang ini didorong oleh inovasi dalam sains dan teknologi yang semakin hari semakin berkembang dan terus berubah. Era disrupsi adalah situasi yang dihadapi manusia modern yang sedang terjadi perubahan fundamental atau mendasar, yaitu evolusi teknologi yang membidik sisi kehidupan manusia. Dengan adanya digitalisasi yang diakibatkan dari evolusi teknologi (terutama informasi) yang mengubah hampir semua tatanan kehidupan, ${ }^{25}$ Era disrupsi ini merupakan fenomena ketika masyarakat menggeser aktivitas-aktivitas yang awalnya dilakukan di dunia nyata, ke dunia maya. ${ }^{26}$ Tidak dipungkiri bahwa gelombang perubahan itu selalu mengejutkan. Setelah melewati tren yang begitu panjang, tiba-tiba manusia harus menghadapi perubahan yang berbeda sama sekali polanya. Seperti saat ini adanya perubahan dengan menggunakan smartphone, ini ciri dari bahwa dunia memasuki era disrupsi. ${ }^{27}$

Era disrupsi merupakan sebuah era peralihan, dimana informasi yang menyebar di media sosial sudah semakin cepat dan efisien, sehingga menimbulkan efek pembaruan di lini informasi secara cepat dan berpengaruh tanpa disadari. ${ }^{28}$ Masa peralihan telah mengubah cara hidup manusia berbeda dari era sebelumnya, perkembangan ini membawa manusia di era yang penuh optimis, cerdas, dan serba praktis dalam melakukan transaksi. Begitu juga yang dinyatakan oleh Kasali bahwa era disrupsi dalam bukunya Self Disruption, bahwa

\footnotetext{
${ }^{22}$ Nasrullah, "Perundungan Siber ( Cyber - Bully Ing ) Di Status Facebook Divisi Humas Mabes Polri."

23 Ibid.

${ }^{24}$ Wisa Febrina Sukmaningtyas, "Penggunaan Jejaring Sosial Pada Perilaku Perundungan Siber Remaja Di Smk Negeri 1 Samarinda," eJournal Ilmu Komunikasi, 2017.

${ }^{25}$ I Wayan Lasmawan, "Era Disrupsi Dan Implikasinya Bagi Reposisi Makna Dan Praktek Pendidikan (Kaji Petik Dalam Perspektif Elektik Sosial Analisis)," Jurnal Media Komunikasi Pendidikan Pancasila dan Kewarganegaraan 1, no. 1 (2019): 54-65.

${ }^{26}$ Ibid.

${ }^{27}$ Widodo Dwi Putro, "Disrupsi Dan Masa Depan Profesi Hukum,” Mimbar Hukum - Fakultas Hukum Universitas Gadjah Mada 32, no. 1 (2020): 19.

${ }^{28}$ Rhenald Kasali, The Great Shifting (Jakarta: Gramedia Pustaka, 2018), 34.
} 
disrupsi adalah adanya perubahan yang terjadi dengan nyata sebagai akibat hadirnya masa depan ke masa kini. ${ }^{29}$

Perkembangan teknologi informasi yang semakin pesat mampu mengubah pola kehidupan masyarakat dalam hal pemenuhan informasi. Segala bentuk informasi dapat menyebar secara cepat bahkan sulit untuk dikontrol. Tidak dapat dipungkiri saat ini manusia semakin dimanjakan dengan berbagai kecanggihan teknologi, mulai dari munculnya alat komunikasi handphone sampai smartphone yang dilengkapi dengan bebagai fitur dan teknologi internet. ${ }^{30}$ Era disrupsi pada awalnya terjadi pada dunia perdagangan atau bisnis yang bergerak dibidang transportasi daring, kemudian inovasi teknologi ini mulai merambat dalam bidang telekomunikasi yang ditandai dengan munculnya aplikasi seperti WhatsApp, Line, Facebook, Instagram, dan aplikasi lainnya, ${ }^{31}$ sehingga komunikasi manusia sangat dimudahkan dan menjadi efektif. Namun perubahan sikap manusia juga mengalami pergeseran dan harus menyesuaikan dengan era yang semakin cepat ini. Manusia dituntut untuk dapat mengikuti perkembangan tersebut, jika tidak maka manusia akan mengalami ketertinggalan terlebih akan tersingkir dengan proses perubahan yang menyeluruh di hampir semua sektor dan tatanan. Perubahan ini mengarahkan individu kepada dua pilihan, yaitu memegang kendali atau dikuasai (dikendalikan oleh perubahan). ${ }^{32}$ Semua itu dipengaruhi oleh dunia yang sedang berkembang ke arah perubahan dengan cepat, terutama perubahan dalam hal teknologi yang terjadi begitu cepat, bahkan perubahan tersebut jauh lebih pesat terjadi dibandingkan abad-abad revolusi industri sebelumnya, ${ }^{33}$ sehingga dapat dikatakan bahwa teknologi mengubah seluruh tatanan manusia yang ada. ${ }^{34}$

\section{Pengaruh Media Sosial dalam Etika}

Media sosial adalah medium di internet yang memungkinkan pengguna merepresentasikan dirinya atau personal branding maupun berinteraksi, sebagai bagian dari makhluk sosial yang bekerja sama, berbagi, berkomunikasi dengan pengguna lain, dan

${ }^{29}$ Rhenald Kasali, Self Disruption (Jakarta: Mizan Anggota IKAPI, 2018), 109.

${ }^{30}$ Hasan Bastomi dan Sri Noor Mustaqimatul Hidayah, "Fenomena Perundungan Di Sosial Media: Telaah Dampak Perundungan Bagi Remaja," AT-TABSYIR: Jurnal Komunikasi Penyiaran Islam 6, no. 1 (2019): 235.

${ }^{31}$ Johanis Ohoitimur, "Tantangan bagi Perkembangan Ilmu Pengetahuan dan Peluang bagi Lembaga Pendidikan Tinggi Johanis Ohoitimur," Respons 23, no. 02 (2018): 143-166.

32 Ajeng Wulansasi dan Ahmad Aji Jauhari Ma'mun, "Kepemimpinan Pendidikan: Menghadapi Disrupsi Dan Vuca Di Masa Depan," MANAGERE : Indonesian Journal of Educational Management 1 (2019): 51-75.

${ }^{33}$ Enggar Objantoro, "Religious Pluralism And Christian Responses," Evangelikal: Jurnal Teologi Injili dan Pembinaan Warga Jemaat (2018). Depan."

${ }^{34}$ Wulansasi dan Ma'mun, “Kepemimpinan Pendidikan: Menghadapi Disrupsi Dan Vuca Di Masa 
membentuk ikatan sosial secara virtual. ${ }^{35}$ Sekitar $70 \%$ dari pengguna internet di seluruh dunia, menggunakan media sosial dengan aktif dalam berjejaring. Media sosial seperti Facebook, Twitter, Instagram, Youtube, dan layanan pesan instan, masih sangat tinggi tingkat penggunanya sampai saat ini. Meski demikian, penggunaan media sosial juga telah menyebabkan banyak konflik dan masalah, antara lain pergeseran budaya dari budaya tradisional menjadi budaya digital. ${ }^{36}$ Media sosial secara garis besar diartikan sebagai media daring berbasis internet yang dapat diakses oleh para penggunanya (user) untuk berbagi, berpartisipasi dan menciptakan suatu konten baru seperti blog, wiki, forum, jejaring sosial maupun ruang dunia virtual yang didukung melalui teknologi multimedia yang sulit untuk dipisahkan satu sama lain. ${ }^{37}$ Media sosial dapat juga disebut dengan jejaring sosial, merupakan bagian dari media baru. Jelas kiranya bahwa muatan interaktif dalam media baru ini aktratif dan sangatlah tinggi, ${ }^{38}$ sehingga pengguna media ini sangatlah beragam dari pertemanan maupun untuk membawa media sosial sebagai bagian dari black campaign.

Lahirnya media sosial menjadikan pola perilaku masyarakat mengalami pergeseran baik budaya, etikan dan norma yang ada. ${ }^{39}$ Kekuatan media sosial untuk mempengaruhi masyarakat didasarkan secara eksklusif pada aspek sosialnya. ${ }^{40}$ Seperti mempengaruhi dalam pemenangan pemilihan presiden ataupun parlemen. Hal itu dikarenakan media sosial adalah sebuah perangkat lunak untuk bersosialisasi satu sama lain dan dilakukan secara daring yang memungkinkan manusia untuk saling berinteraksi tanpa dibatasi ruang dan waktu. ${ }^{41}$ Pengaruh media sosial sangat besar hingga dapat membuat seseorang yang awalnya biasa saja bisa menjadi besar dan terkenal, atau sebaliknya harus terjun bebas dalam kebangkrutan, maupun menngung malu akibat perbuatannya yang melanggar Undangundang ITE. ${ }^{42}$

\footnotetext{
${ }^{35}$ Febrina Sukmaningtyas, "Penggunaan Jejaring Sosial Pada Perilaku Perundungan Siber Remaja Di Smk Negeri 1 Samarinda."

${ }^{36}$ Fahmi Anwar, "Perubahan dan Permasalahan Media Sosial," Jurnal Muara Ilmu Sosial, Humaniora, dan Seni (2017).

${ }^{37}$ Anisa Rohmawati, "Pengaruh Penggunaan Media Sosial Terhadap Etika Pergaulan Antar Lawan Jenis Di Kalangan Remaja Islam,” Jurnal Bimbingan Konseling (2019).

${ }^{38}$ Errika Dwi Setya Watie, "Komunikasi dan media sosial (communications and social media)," Jurnal The Messenger 3, no. 2 (2016): 69-74.

${ }^{39}$ Anang Sugeng Cahyono, "Pengaruh Media Sosial Terhadap Perubahan Sosial Masyarakat di Indonesia," Jurnal Publiciana (2016): 140-157.

${ }^{40}$ Berliani Ardha, "Social Media sebagai media kampanye partai politik 2014 di Indonesia," Visi Komunikasi (2014).

${ }^{41}$ Rafi Saumi Rustian, "Apa itu Sosial Media,” 01 Maret 2012, 2012.

${ }^{42}$ Wilga Secsio Ratsja Putri, Nunung Nurwati, dan Meilanny Budiarti S., "Pengaruh Media Sosial Terhadap Perilaku Remaja," Prosiding Penelitian dan Pengabdian kepada Masyarakat 3, no. 1 (2016).
} 
Penyalahgunaan media sosial dapat saja menghasilkan perilaku komunikasi sosial yang buruk. Tidak heran jika ada perilaku pengabaian orang lain dalam berinteraksi karena perhatian yang lebih tertuju kepada ponsel (phubbing), perundungan (bullying) dan pencurian data untuk penipuan. ${ }^{43}$ Pengguna media sosial dan sarana komunikasi daring lainnya menggunakan akun pribadinya untuk memfitnah, melakukan tindakan perundungan, bahkan sampai menyebarkan berita hoaks, ${ }^{44}$ sehingga media sosial telah mempengaruhi seluruh kehidupan sosial dalam lapisan masyarakat. Perubahan-perubahan dalam hubungan sosial (social relationships) atau sebagai perubahan terhadap keseimbangan (equilibrium) hubungan sosial dan segala bentuk perubahan-perubahan pada lembaga-lembaga kemasyarakatan di dalam suatu masyarakat, yang mempengaruhi sistem sosialnya, termasuk di dalamnya nilai-nilai, sikap dan pola perilaku di antara kelompok-kelompok atau organisasi dalam berbagai masyarakat. ${ }^{45}$

\section{Perundungan dalam pandangan iman Kristen}

Perkelahian yang berujung maut, tindakan perundungan dan kekerasan, pengedaran dan penggunaan narkoba, seks bebas, aborsi, pelecehan seksual, pemerkosaan, pembunuhan, pencurian, pembobolan rekening bank ataupun perusakan data privasi seseorang atau suatu perusahaan adalah beberapa contoh tindakan yang tidak terpuji. ${ }^{46}$ Dalam hal ini perundungan adalah tindakan penggunaan kekuasaan untuk menyakiti seseorang atau sekelompok orang baik secara verbal, fisik, maupun psikologis sehingga korban merasa tertekan, trauma, dan tak berdaya, ${ }^{47}$ yang dilakukan oleh orang lain kepada seseorang secara terus-menerus dan berulang baik secara fisik maupun psikis. Hal ini dapat disebut juga perilaku agresif yang menyebabkan adanya korban, ${ }^{48}$ sehingga berdampak bagi anak-anak akan menunjukkan sifat kekerasan, ${ }^{49}$ terlebih akan mengalami penurunan prestasi akademik

\footnotetext{
${ }^{43}$ Ruat Diana, "Peran Komunikator Kristen dalam Strategi Pekabaran Injil di Era Revolusi Industri 4.0,” Integritas: Jurnal Teologi (2019).

${ }^{44}$ Yosua Feliciano Camerling, Mershy Ch. Lauled, dan Sarah Citra Eunike, "Gereja Bermisi Melalui Media Digital Di Era Revolusi Industri 4.0," Visio Dei: Jurnal Teologi Kristen 2, no. 1 (2020): 1-22.

${ }^{45}$ Cahyono, "Pengaruh Media Sosial Terhadap Perubahan Sosial Masyarakat di Indonesia."

46 S Matondang, "Memahami Identitas Diri Remaja dalam Kristus Menurut Efesus 2:1-10," ILLUMINATE: Jurnal Teologi dan Pendidikan Agama Kristen 1, no. 1 (2018): 105-124.

${ }^{47}$ ELA ZAIN ZAKIYAH, SAHADI HUMAEDI, dan MEILANNY BUDIARTI SANTOSO, "Faktor Yang Mempengaruhi Remaja Dalam Melakukan Bullying," Prosiding Penelitian dan Pengabdian kepada Masyarakat 4, no. 2 (2017).

${ }^{48}$ Novi Herawati dan Deharnita, "Gambaran Faktor-Faktor Penyebab Terjadinya Perilaku Bullying pada Anak," Jurnal Keperawatan 15, no. 1 (2019): 60-66.

${ }^{49}$ ZAKIYAH, HUMAEDI, dan SANTOSO, "Faktor Yang Mempengaruhi Remaja Dalam Melakukan Bullying."
} 
dan gangguan mental yang akan menghambat proses tumbuh kembang pribadinya. ${ }^{50}$ Bahkan ujaran kebencian (hate speech) selalu ada mengiringi kebebasan berpendapat di media sosial. ${ }^{51}$ Oleh karena itu, masyarakat seharusnya mewaspadai kebebasan berekspresi serta tetap berpegang pada etika komunikasi dan pengendalian diri yang baik. ${ }^{52}$

Perundungan adalah suatu perbuatan yang melanggar firman dan itu berarti dosa, seperti yang dinyatakan oleh Tuhan Yesus "Tetapi Aku berkata kepadamu: Setiap orang yang marah terhadap saudaranya harus dihukum; siapa yang berkata kepada saudaranya: Kafir! harus dihadapkan ke Mahkamah Agama dan siapa yang berkata: Jahil! harus diserahkan ke dalam neraka yang menyala-nyala." (Matius 5: 22) perkataan yang seperti ini jika dilakukan tanpa suatu tujuan yang baik, melainkan hanya sekadar untuk memamerkan kekuasaan, memuaskan nafsu kedagingan, untuk menunjukkan kekesalan kita kepada orang, dan memanasi diri guna membalas dendam. Kemarahan semacam ini sia-sia sifatnya. hanya menyakiti hati saja. ${ }^{53}$

Kristus berkata kepada mereka bahwa menggunakan kata-kata keji kepada saudara orang percaya adalah pembunuhan dengan lidah, seperti misalnya menyebutnya kafir dan jahil. ${ }^{54}$ Ucapan kafir adalah perkataan yang menghina dan keluar dari kesombongan. Sedangkan ucapan "Kamu orang yang tidak berguna" adalah kata-kata yang disebut Salomo sebagai pencemooh yang sombong (Ams. 21:24), yang menginjak-injak saudara kita yang dipandang terlalu hina untuk ditempatkan bersama-sama dengan anjing penjaga kambing domba. Tutur kata lain yang seperti ini adalah, "Orang banyak ini yang tidak mengenal hukum Taurat, terkutuklah mereka" (Yoh. 7:49). ${ }^{55}$ Seperti yang diungkapkan dalam Yohanes: Setiap orang yang membenci saudaranya, adalah seorang pembunuh manusia. Dan kamu tahu, bahwa tidak ada seorang pembunuh yang tetap memiliki hidup yang kekal di dalam dirinya. (1Yoh. 3:15).

Yesus menegaskan kembali bahwa apa yang dilakukan dan diperkatakan terhadap sesama suatu saat harus dipertanggungjawabkan semuanya. Orang yang marah terhadap saudaranya berada dalam bahaya akan dihukum dan dimurkai Allah. Orang yang berkata,

\footnotetext{
${ }^{50}$ Citra Putri Wijayanti dan Ayu Tipa Uswatun, "Perangi Tindak Perundungan (Bullying) dengan Penanaman Pendidikan Karakter Sejak Dini Pada Peserta Didik Sekolah Dasar," in Prosiding Seminar Nasional Pagelaran Pendidikan Dasar Nasional (Ppdn) 2019, vol. 1, 2019, 16-26.

51 Vibriza Juliswara, "Mengembangkan Model Literasi Media yang Berkebhinnekaan dalam Menganalisis Informasi Berita Palsu (Hoax) di Media Sosial," Jurnal Pemikiran Sosiologi (2017).

${ }^{52}$ Anwar, "Perubahan dan Permasalahan Media Sosial."

53 Henry's Matthew, "Matthew Henry Commentary On Whole Bible," last modified 2002, https://www.biblestudytools.com/commentaries/matthew-henry-complete/Matiusl/2.html.

54 Ibid.

55 Ibid.
} 
"Kafir!" harus dihadapkan ke Mahkamah Agama dan dihukum oleh dewan Sanhedrin karena mencerca orang Israel. Tetapi siapa yang berkata, "Jahil, orang celaka, anak neraka," akan diserahkan ke dalam neraka yang menyala-nyala karena mengutuki saudaranya. ${ }^{56}$ Begitu juga Rasul Paulus dalam menyampaikan pesannya kepada jemaat di Roma dengan mengatakan "Karena itu, hai manusia, siapapun juga engkau, yang menghakimi orang lain, engkau sendiri tidak bebas dari salah. Sebab, dalam menghakimi orang lain, engkau menghakimi dirimu sendiri, karena engkau yang menghakimi orang lain, melakukan hal-hal yang sama." (Rm. 2:1). Begitu juga dalam kitab Amsal yang mengungkapkan "Siapa menghina sesamanya berbuat dosa, tetapi berbahagialah orang yang menaruh belas kasihan kepada orang yang menderita." (Ams. 14:21), lebih jelas lagi bahwa segala hal yang berkaitan dengan merendahkan diri orang lain adalah tindakan yang tidak berakal budi "Siapa menghina sesamanya, tidak berakal budi." Untuk itu orang percaya harus mengunakan perkataan, dan sikap bahasa tubuh dengan tetap menghargai orang lain terlebih gunakan humor yang benar-benar yang bebas dari merendahkan martabat dan harkat manusia.

\section{Peran Orang percaya dalam Menghadapi Perundungan di Era Disrupsi}

Perundungan, baik dalam dunia nyata dan maupun maya, adalah kejahatan serius yang berkaitan dengan merendahkan manusia. Perundungan maya adalah kesengajaan, perulangan perilaku, maupun kebiasaan negatif dengan menggunakan teknologi informasi dan komunikasi seperti email, pesan instan, sampai situs personal oleh individu maupun kelompok dengan maksud menyakiti orang lain. ${ }^{57}$ Maraknya kasus kejahatan di dunia maya khususnya terkait kejahatan Cyber Bullying terus menerus meningkat dari tahun ke tahun. ${ }^{58}$ Hal perilaku perundungan itu banyak terjadi di sekolah, tetapi masih jarang sekali diperhatikan oleh para pendidik atau guru, sehingga banyak diantara mereka hal tersebut sangat lumrah, padahal itu merupakan perilaku yang tidak baik. ${ }^{59}$ Namun tidak kalah lagi dunia media sosial saat ini diisi oleh cacian dan makian kepada individu maupun pemerintah. Padahal upaya pemerintah dalam menanggulangi kasus ini dengan mengeluarkan peraturan

\footnotetext{
56 Ibid.

${ }^{57}$ Nasrullah, "Perundungan Siber ( Cyber - Bully Ing ) Di Status Facebook Divisi Humas Mabes Polri."

${ }^{58}$ Suryanto, "Perundungan Dunia Maya (Cyber Bullying) Menurut Undang-Undang Ri No. 19 Tahun 2016 Tentang Informasi Transaksi Elektronik Dan Hukum Islam,” Raden Fatah (2016).

59 Sucipto Sucipto, "Bullying dan Upaya Meminimalisasikannya," PSIKOPEDAGOGIA Jurnal Bimbingan dan Konseling 1, no. 1 (2012).
} 
yang lebih khusus untuk menjamin keamanan dalam bidang Informasi Transaksi Elektronik dengan membuat UU No.11 Tahun 2008 jo UU No.19 Tahun $2016 .^{60}$

Internet adalah media yang dianggap tepat sebagai wadah ekspresi mereka karena nitizen mempunyai pandangan yang luas dan bebas untuk melakukan apapun di dunia internet, ${ }^{61}$ tetapi bisa meningkatkan kejahatan dan penyalahgunaan yang mengkhawatirkan, ${ }^{62}$ sebab siapa pun memiliki potensi untuk menjadi korban dan pelaku perundungan siber. ${ }^{63}$ Untuk itu orang percaya harus melatih dan membiasakan anak memiliki perilaku menghargai, dimulai dalam keluarga dan lembaga pendidikan formal pada usia dini dapat dilakukan, ${ }^{64}$ dan menanamkan nilai-nilai Alkitabiah bagi setiap orang yang percaya kepada Yesus, seperti yang diungkapkan Yesus, "Tetapi kepada kamu, yang mendengarkan Aku, Aku berkata: Kasihilah musuhmu, berbuatlah baik kepada orang yang membenci kamu; mintalah berkat bagi orang yang mengutuk kamu; berdoalah bagi orang yang mencaci kamu. (Luk. 6:27-28) Yesus jelas mengajarkan saling mengasihi dan saling menghargai, ajaran Yesus tidak bertentangan dengan norma dan hukum yang ada dimanapun. Kekristenan dituntut untuk peduli dan turut campur dalam kasus perundungan baik yang saat menghadapi bullyian maupun melihat dalam situasi orang lain dibully.

Yesus mengajarkan kepada orang percaya untuk memiliki respon menghadapi masalah dengan benar dengan tidak membalas segala hal yang merendahkan hidup. Ajaran Yesus yang harus dilakukan adalah memberikan pipi kiri, atau membela dan menjadikan ajang untuk saling membalas dendam. Yesus menyarankan untuk memberi pipi kiri (Mat. 5:38-42), Ia mengajarkan kepada orang percaya untuk tidak membalas serangan pribadi. Gagasan dan esensi dari pernyataan Yesus adalah tidak membalas cacian, hinaan dengan cacian atau hinaan juga, namun harus menahan diri untuk tidak membalasnya. Sebab perbuatan untuk membalas tindasan seorang penindas atau perundung tidak alkitabiah dan tidak bermanfaat bagi pribadi orang percaya. Seperti juga yang dinyatakan oleh Rasul Paulus dalam Roma 12:17-21, "Janganlah membalas kejahatan dengan kejahatan; lakukanlah apa yang baik bagi semua orang! Sedapat-dapatnya, kalau hal itu bergantung

\footnotetext{
${ }^{60}$ Suryanto, "Perundungan Dunia Maya (Cyber Bullying) Menurut Undang-Undang Ri No. 19 Tahun 2016 Tentang Informasi Transaksi Elektronik Dan Hukum Islam."

${ }^{61}$ Bastomi dan Mustaqimatul Hidayah, "Fenomena Perundungan Di Sosial Media: Telaah Dampak Perundungan Bagi Remaja."

${ }^{62}$ David Alinurdin, "Etika Kristen Dan Teknologi Informasi: Sebuah Tinjauan Menurut Perspektif Alkitab,"Veritas : Jurnal Teologi dan Pelayanan 17, no. 2 (2018): 91-105. Pelaku."

${ }^{63}$ Rastati, "Bentuk Perundungan Siber Di Media Sosial Dan Pencegahannya Bagi Korban Dan

64 Nursasari, "Penerapan Antisipasi Perundungan (Bullying) pada Sekolah Dasar di Kota Tenggarong."
} 
padamu, hiduplah dalam perdamaian dengan semua orang! Saudara-saudaraku yang kekasih, janganlah kamu sendiri menuntut pembalasan, tetapi berilah tempat kepada murka Allah, sebab ada tertulis: Pembalasan itu adalah hak-Ku. Akulah yang akan menuntut pembalasan, firman Tuhan. Tetapi, jika seterumu lapar, berilah dia makan; jika ia haus, berilah dia minum! Dengan berbuat demikian kamu menumpukkan bara api di atas kepalanya. Janganlah kamu kalah terhadap kejahatan, tetapi kalahkanlah kejahatan dengan kebaikan!" dan terlebih juga orang percaya harus memiliki moral yang sesuai dengan kebenaran firman Allah sebagai contoh menggunakan mulut dengan bijaksana. Janganlah ada perkataan kotor keluar dari mulutmu, tetapi pakailah perkataan yang baik untuk membangun, di mana perlu, supaya mereka yang mendengarnya, beroleh kasih karunia.(Efesus 4:29).

Rasul Paulus menasihatkan orang percaya hidup dalam perdamaian dengan sesama "Sedapat-dapatnya, kalau hal itu bergantung padamu, hiduplah dalam perdamaian dengan semua orang! Saudara-saudaraku yang kekasih, janganlah kamu sendiri menuntut pembalasan, tetapi berilah tempat kepada murka Allah, sebab ada tertulis: Pembalasan itu adalah hak-Ku. Akulah yang akan menuntut pembalasan, firman Tuhan. (Roma 12:18-19) Sebagai orang percaya apapun bentuk bullying adalah tindakan yang harus ditolak. Sekecil apapun dalam perundungan adalah prilaku yang jauh dari kebenaran firman Allah untuk itu sebagai orang yang beriman kepada Yesus untuk tetap peduli dengan sesama baik yang seiman maupun tidak harus menolak bullying. Orang percaya harus mempunyai perseptif dari Alkitab untuk tetap menerima segala perbedaan baik fisik, ide, dan segala hal serta mau hidup berdampingan untuk terus menjadi garam dan terang seperti yang diinginkan Yesus dalam kehidupan kekristenan. Untuk itu setiap orang percaya memerlukan hikmat dari Allah $^{65}$ untuk menanggapi perundungan. Orang percaya juga harus mengikuti perintah Alkitab dan hidup dalam pimpinan Roh Kudus sebab Roh Kudus memberikan hikmat dan pengertian untuk mengenal Yesus dan menghayatinya di setiap langkah perjalanan hidup. ${ }^{66}$

\section{KESIMPULAN}

Perundungan adalah hal yang bertentangan dengan firman Tuhan, konsep iman Kristen sangat menolak apapun bentuk penindasan. Perundungan mengakibatkan banyak

\footnotetext{
${ }^{65}$ Joseph Christ Santo, "Makna dan Penerapan Frasa Mata Hati yang Diterangi dalam Efesus 1: 1819," Jurnal Teologi Berita Hidup 1, no. 1 (Oktober 18, 2018): 1-12.

${ }^{66}$ Yonatan Alex Arifianto dan Asih Rachmani Endang Sumiwi, "Peran Roh Kudus Dalam Menuntun Orang Percaya Kepada Seluruh Kebenaran Berdasarkan Yohanes 16: 13," DIEGESIS: Jurnal Teologi Kharismatika 3, no. 1 (2020): 1-12.
} 
dampak negatif. Sebagai orang percaya pembelaan diri harus dilakukan dengan mengikuti nilai firman dan Hukum yang berlaku, namun tetap menyerahkan segala apa yang dihadapi dalam penindasan atau perundungan kepada Tuhan sebagai hakim.

Dapat disimpulkan bahwa dalam menghadapi perundungan di tengah disrupsi, bahwa orang percaya harus mengetahui era disrupsi dalam perkembangan sosial manusia, lalu memahami adanya pengaruh media sosial dalam etika, dan mencermati bagaimana pandangan iman Kristen dalam menghadapi perundungan. Dengan berpegang pada pandangan bahwa keberadaan orang Kristen harus menjadi garam dan terang dunia, berarti harus siap hidup berdampingan dengan perbedaan fisik, ide, dan segala hal lainnya.

\section{REFERENSI}

Alinurdin, David. "Etika Kristen Dan Teknologi Informasi: Sebuah Tinjauan Menurut Perspektif Alkitab.” Veritas : Jurnal Teologi dan Pelayanan 17, no. 2 (2018): 91-105.

Anwar, Fahmi. "Perubahan dan Permasalahan Media Sosial." Jurnal Muara Ilmu Sosial, Humaniora, dan Seni (2017).

Ardha, Berliani. "Social Media sebagai media kampanye partai politik 2014 di Indonesia." Visi Komunikasi (2014).

Arifianto, Yonatan Alex, dan Asih Rachmani Endang Sumiwi. "Peran Roh Kudus Dalam Menuntun Orang Percaya Kepada Seluruh Kebenaran Berdasarkan Yohanes 16: 13." DIEGESIS: Jurnal Teologi Kharismatika 3, no. 1 (2020): 1-12.

Bastomi, Hasan, dan Sri Noor Mustaqimatul Hidayah. "Fenomena Perundungan Di Sosial Media: Telaah Dampak Perundungan Bagi Remaja." AT-TABSYIR: Jurnal Komunikasi Penyiaran Islam 6, no. 1 (2019): 235.

Borualogo, Ihsana Sabriani, Hedi Wahyudi, dan Sulisworo Kusdiyati. "Prediktor perundungan siswa sekolah dasar." Jurnal Ilmiah Psikologi Terapan 8, no. 1 (2020): 35 .

Cahyono, Anang Sugeng. "Pengaruh Media Sosial Terhadap Perubahan Sosial Masyarakat di Indonesia." Jurnal Publiciana (2016): 140-157.

Camerling, Yosua Feliciano, Mershy Ch. Lauled, dan Sarah Citra Eunike. "Gereja Bermisi Melalui Media Digital Di Era Revolusi Industri 4.0." Visio Dei: Jurnal Teologi Kristen 2, no. 1 (2020): 1-22.

Dan, Sartana, dan Nelia Afriyeni. "Perilaku Perundungan Maya (Cyberbullying) Pada Remaja Awal." Jurnal Psikologi Insight (C Psikologi Universitas Pendidikan Indonesia 1, no. 1 (2017): 25-41.

Denney, Andrew S., dan Richard Tewksbury. "How to Write a Literature Review." Journal of Criminal Justice Education 24, no. 2 (2013): 218-234.

Diana, Ruat. "Peran Komunikator Kristen dalam Strategi Pekabaran Injil di Era Revolusi Industri 4.0." Integritas: Jurnal Teologi (2019).

Dwi Putro, Widodo. "Disrupsi Dan Masa Depan Profesi Hukum.” Mimbar Hukum - Fakultas Hukum Universitas Gadjah Mada 32, no. 1 (2020): 19.

Febrina Sukmaningtyas, Wisa. "Penggunaan Jejaring Sosial Pada Perilaku Perundungan Siber Remaja Di Smk Negeri 1 Samarinda." eJournal Ilmu Komunikasi, 2017.

Henry's Matthew. "Matthew Henry Commentary On Whole Bible."

Herawati, Novi, dan Deharnita. "Gambaran Faktor-Faktor Penyebab Terjadinya Perilaku Bullying pada Anak." Jurnal Keperawatan 15, no. 1 (2019): 60-66. 
Juliswara, Vibriza. "Mengembangkan Model Literasi Media yang Berkebhinnekaan dalam Menganalisis Informasi Berita Palsu (Hoax) di Media Sosial." Jurnal Pemikiran Sosiologi (2017).

Kartikosari, Rini, dan Imam Setyawan. "Hubungan Kecerdasan Interpersonal Dengan Intensi Perundungan Pada Siswa Sekolah Menengah Pertama H. Isriati Semarang." Empati 7, no. 2 (2018): 182-188.

Kasali, Rhenald. Self Disruption. Jakarta: Mizan Anggota IKAPI, 2018.

Lasmawan, I Wayan. "Era Disrupsi Dan Implikasinya Bagi Reposisi Makna Dan Praktek Pendidikan (Kaji Petik Dalam Perspektif Elektik Sosial Analisis)." Jurnal Media Komunikasi Pendidikan Pancasila dan Kewarganegaraan 1, no. 1 (2019): 54-65.

Matondang, S. "Memahami Identitas Diri Remaja dalam Kristus Menurut Efesus 2:1-10." ILLUMINATE: Jurnal Teologi dan Pendidikan Agama Kristen 1, no. 1 (2018): 105124.

Nasrullah, Rulli. "Perundungan Siber ( Cyber - Bully Ing ) Di Status Facebook Divisi Humas Mabes Polri." Jurnal Sosioteknologi 14, no. 1 (2015): 1-11.

Nursasari, Nursasari. "Penerapan Antisipasi Perundungan (Bullying) pada Sekolah Dasar di Kota Tenggarong." SYAMIL: Jurnal Pendidikan Agama Islam (Journal of Islamic Education) 5, no. 2 (2017).

Objantoro, Enggar. "Religious Pluralism And Christian Responses." Evangelikal: Jurnal Teologi Injili dan Pembinaan Warga Jemaat (2018).

Ohoitimur, Johanis. "Tantangan bagi Perkembangan Ilmu Pengetahuan dan Peluang bagi Lembaga Pendidikan Tinggi Johanis Ohoitimur." Respons 23, no. 02 (2018): 143-166. Patchin, Justin W., dan Sameer Hinduja. "Bullies Move Beyond the Schoolyard: A Preliminary Look at Cyberbullying." Youth Violence and Juvenile Justice 4, no. 2 (2006): 148-169.

Putri, Fildzah Rudyah. "Hubungan Pola Asuh Otoriter Terhadap Perilaku Perundungan Pada Remaja." JKKP (Jurnal Kesejahteraan Keluarga dan Pendidikan) 5, no. 2 (2018): 101108.

Putri, Wilga Secsio Ratsja, Nunung Nurwati, dan Meilanny Budiarti S. "Pengaruh Media Sosial Terhadap Perilaku Remaja." Prosiding Penelitian dan Pengabdian kepada Masyarakat 3, no. 1 (2016).

Rafi Saumi Rustian. “Apa itu Sosial Media.” 01 Maret 2012, 2012.

Ramdhani, Neila. "Emosi Moral dan Empati pada Pelaku Perundungan-siber." Jurnal Psikologi 43, no. 1 (2016): 66.

Rastati, Ranny. "Bentuk Perundungan Siber Di Media Sosial Dan Pencegahannya Bagi Korban Dan Pelaku." Jurnal Sosioteknologi 15, no. 2 (2016): 169-186.

Rhenald, Kasali. The Great Shifting. Jakarta: Gramedia Pustaka, 2018.

Rohmawati, Anisa. "Pengaruh Penggunaan Media Sosial Terhadap Etika Pergaulan Antar Lawan Jenis Di Kalangan Remaja Islam.” Jurnal Bimbingan Konseling (2019).

Rozaliyani, Anna, Broto Wasisto, Frans Santosa, R Sjamsuhidajat, Rianto Setiabudy, Pukovisa Prawiroharjo, Muhammad Baharudin, dan Ali Sulaiman. "Bullying (Perundungan) di Lingkungan Pendidikan Kedokteran." Jurnal Etika Kedokteran Indonesia 3, no. 2 (2019): 56.

Santo, Joseph Christ. "Makna dan Penerapan Frasa Mata Hati yang Diterangi dalam Efesus 1: 18-19." Jurnal Teologi Berita Hidup 1, no. 1 (Oktober 18, 2018): 1-12.

Sucipto, Sucipto. "Bullying dan Upaya Meminimalisasikannya." PSIKOPEDAGOGIA Jurnal Bimbingan dan Konseling 1, no. 1 (2012).

Suryanto. "Perundungan Dunia Maya (Cyber Bullying) Menurut Undang-Undang Ri No. 19 Tahun 2016 Tentang Informasi Transaksi Elektronik Dan Hukum Islam.” Raden Fatah (2016). 
Watie, Errika Dwi Setya. "Komunikasi dan media sosial (communications and social media)." Jurnal The Messenger 3, no. 2 (2016): 69-74.

Wijayanti, Citra Putri, dan Ayu Tipa Uswatun. "Perangi Tindak Perundungan (Bullying) dengan Penanaman Pendidikan Karakter Sejak Dini Pada Peserta Didik Sekolah Dasar." In Prosiding Seminar Nasional Pagelaran Pendidikan Dasar Nasional (Ppdn) 2019, 1:16-26, 2019.

Wulansasi, Ajeng, dan Ahmad Aji Jauhari Ma'mun. "Kepemimpinan Pendidikan: Menghadapi Disrupsi Dan Vuca Di Masa Depan." MANAGERE : Indonesian Journal of Educational Management 1 (2019): 51-75.

ZAKIYAH, ELA ZAIN, SAHADI HUMAEDI, dan MEILANNY BUDIARTI SANTOSO. "Faktor Yang Mempengaruhi Remaja Dalam Melakukan Bullying." Prosiding Penelitian dan Pengabdian kepada Masyarakat 4, no. 2 (2017).

Zaluchu, Sonny Eli. "Strategi Penelitian Kualitatif dan Kuantitatif Di Dalam Penelitian Agama." Evangelikal: Jurnal Teologi Injili dan Pembinaan Warga Jemaat 4, no. 1 (2020): 28-38. 